\title{
STEADY-STATE ANALYSIS ON COOLANT SYSTEM OPERATING OF THE TRIGA2000 USING FUEL PLATE TYPE
}

\author{
Sukmanto Dibyo', Ign Djoko Irianto', Veronika Indriati Sri Wardhani² \\ ${ }^{1}$ Center for Nuclear Reactor Safety and Technology, Batan \\ ${ }^{2}$ Center for Applied Nuclear Science and Technology, Batan \\ Email: sukdibyo@batan.go.id.
}

Diterima: 28 April 2021, diperbaiki : 29 April 2021, disetujui : 30 April 2021

\begin{abstract}
STEADY-STATE ANALYSIS ON COOLANT SYSTEM OPERATING OF THE TRIGA2000 USING FUEL PLATE TYPE. The TRIGA2000 is one of the nuclear research reactors in Indonesia. TRIGA reactor fuel element is rod type, studies of the TRIGA reactor using plate type fuel have been carried out. One primary coolant pump is required to overcome the safety factor on the core which uses plate-type fuel. Besides that, changes in the reactor core configuration have an effect on the ability to transfer heat from the core to the coolant. Therefore, it is necessary to analyze the operating parameters of the cooling system including temperature, pressure and flow rate. This operating data is important, which is required by the operator to estimate the reactor coolant condition. The purpose of this paper is to analyze the cooling system parameters under normal steady-state operation where the primary coolant capacity is $50 \mathrm{~kg} / \mathrm{s}$ and the reactor power is determined to be $1 \mathrm{MW}$. Calculation of cooling system at normal condition is carried out using the ChemCAD.6.1.4 computer program. This is also required in providing the reactor's Safety Analysis Report (SAR) document. The results show that the TRIGA reactor which uses plate-type fuel elements can be operated safely. However, in case of coolant temperature to the reactor core exceeding the design data $\left(35^{\circ} \mathrm{C}\right)$, it is necessary to be considered against the operational reliability of the cooling system.
\end{abstract}

Keywords : TRIGA2000; plate-type fuel element; cooling system; steady-state

\section{ABSTRAK}

\begin{abstract}
ANALISIS KEADAAN TUNAK OPERASI SISTEM PENDINGIN TRIGA2000 MENGGUNAKAN ELEMEN BAKAR TIPE PLAT. TRIGA2000 adalah salah satu reaktor riset nuklir di Indonesia. Elemen bahan bakar reaktor TRIGA adalah tipe batang, studi reaktor TRIGA yang menggunakan bahan bakar tipe pelat telah dilakukan. Satu pompa pendingin primer digunakan untuk mengatasi faktor keselamatan pada teras yang menggunakan bahan bakar tipe pelat. Selain itu, perubahan konfigurasi teras reaktor berpengaruh terhadap kemampuan perpindahan panas dari teras ke pendingin. Oleh karena itu, perlu dilakukan analisis terhadap parameter pengoperasian sistem pendingin yang meliputi temperatur, tekanan dan laju aliran. Data operasi ini penting dibutuhkan oleh operator untuk memperkirakan kondisi pendingin reaktor. Makalah ini bertujuan untuk menganalisis parameter sistem pendingin pada operasi kondisi tunak normal dimana kapasitas pendingin primer adalah $50 \mathrm{~kg} / \mathrm{s}$ dan daya reaktor ditentukan sebesar $1 \mathrm{MW}$. Perhitungan sistem pendingin pada kondisi normal dilakukan dengan menggunakan program komputer ChemCAD.6.1.4. Analisis ini juga diperlukan dalam menyediakan dokumen Laporan Analisis Keselamatan (LAK) reaktor. Hasil penelitian menunjukkan bahwa reaktor TRIGA yang menggunakan elemen bahan bakar tipe plat dapat dioperasikan dengan aman. Namun, jika temperatur aliran pendingin ke teras reaktor melebihi data desain $\left(35^{\circ} \mathrm{C}\right)$, maka perlu ditinjau keandalannya terhadap operasi sistem pendingin.
\end{abstract}

Kata kunci : TRIGA2000; elemen bahan bakar tipe plat; sistem pendingin; kondisi tunak 


\section{INTRODUCTION}

$\mathrm{T}$ riga Mark II Bandung (now called triga2000) is the nuclear research reactors in Indonesia that have been in operation since 1965. It is used for nuclear technology research and isotope production [1]. The reactor has been operating for a long time and the supply of reactor fuel elements is limited, which is a challenge for the continuity of reactor operation. In this case, there are two options in the future, namely continuing to operate or decommissioning (the operation will have an impact on the continuity of research, especially related to nuclear analysis). Otherwise, to maintain the continuity of the reactor operation due to the limited availability of fuel, efforts should be made to replace the fuel elements that have been produced by General Atomic USA [2].

As we know, the TRIGA reactor fuel element of a rod-type is common in the world. Since the production of TRIGA fuel was discontinued, the study of neutronic using the fuel type plate has been carried out several times [3][4]. Therefore, an analysis of the reactor cooling system is part of a study in supporting the replacement of these fuels. Besides that, the analysis has been also conducted include the thermal-hydraulics core design $[5][6]$. The use of plate-type fuel in the TRIGA reactor core demands a change in the cooling of the reactor core from natural convection mode to forced convection mode ${ }^{[7]}$. Currently, the capability of the reactor cooling system is supported by two pump units in the primary cooling system and the secondary cooling system. Only one pump unit is operated in the primary cooling system with a mass flow rate of $50 \mathrm{~kg} / \mathrm{s}$. The primary cooling system removes heat from the reactor core to be transferred to the secondary coolant and then released into the environment. The cooling system is equipped with 1 heat exchanger unit, and 2 cooling tower units. Meanwhile, in case the reactor is operated at a power of $2 \mathrm{MW}$ using a plate-type fuel element, at least a mass flow rate of $70 \mathrm{~kg} / \mathrm{s}$ is required [6]. Otherwise, the evaluation results do not recommend two primary coolant pump units to flow the coolant needed to take heat from the reactor [8][9]. For the existing cooling system piping to change the fewest possible and consider safety requirements [10], it is necessary to re-analyze the reactor cooling system. Thus, the conversion of TRIGA using plate-type fuel can be carried out in an integrated manner. To calculate the cooling system parameters, the ChemCAD.6.1.4 program is applied. It can be used to determine the characteristics of the reactor cooling system under normal operation (steadystate). This computer program has been widely used for the process of modeling and simulating cooling systems in the chemical industry and energy plant [11][12].

This study aims to analyze the operating parameters of the reactor cooling system. Which include temperature, pressure, and coolant mass flow rate. The reactor is operated at the power of $1 \mathrm{MW}$ with a primary coolant mass flow rate capacity of $50 \mathrm{~kg} / \mathrm{s}$. Therefore, based on this input data, the existing cooling system operating parameters can be re-analyzed.

The coolant system operation data resulting from this analysis is useful for the operator as an estimate and reference in operating the reactor cooling system.

\section{REACTOR DESCRIPTION}

As a research reactor, this reactor is used as a fission reaction medium which produces a neutron flux for material radiation, while the heat energy from the reactor is released to the environment through the cooling system. This reactor is 
an open pool type, the reactor core is placed at the bottom of the pool which is cooled by natural convection cooling system mode. Currently, the TRIGA Bandung reactor can still operate using a standard rod-type fuel element. The reactor core is cooled by natural circulation flow in the reactor pool [13]. The inlet pipe is placed at the bottom of the core, while the outlet pipe is located near the surface of the tank. The reactor has two cooling system loops, namely:

1) Primary cooling system

2) Secondary cooling system.

The primary cooling system uses demineralized water. It is a coolant circulation loop to take energy in the form of heat from the water in the reactor tank to the secondary cooling system through a plate-frame-type heat exchanger. The secondary cooling system removes heat from the primary cooling system to be released into the environment through the cooling tower. The secondary cooling system is capable of operating continuously. The two loops of the reactor cooling system are also used as a decay heat release system, either when the reactor is in operation or the reactor is at shut-down.
To flow the cooling water, a centrifugal pump is used. Two pumps are installed in parallel and only one pump is used when operating the cooling system. The second pump is used as a back-up redundancy cooling system as in general nuclear reactor cooling system installations. As shown in Figure 1, each cooling system line is equipped with 2 centrifugal pumps, 1 heat exchanger and 2 cooling tower systems.

Furthermore, in the modification of the reactor cooling system, there is a change in the primary cooling system loop, namely, the cooling of the reactor core is changed from a natural convection circulation mode to a forced convection mode. Due to the coolant from the core flows directly to the outlet of the reactor pool, the pipe is equipped with the addition of a delay tank N-16 which is installed in the suction pipe of the pump [14][15]. This tank is used as a decay chamber for the $\mathrm{N}-16$ isotope (half-life of 7.14 seconds) which is carried by cooling water from the reactor core [16]. Further, in order to change the direction of coolant flow into the core from upstream to downstream, the suction pipe to the core is placed at the top of the reactor pool [17].

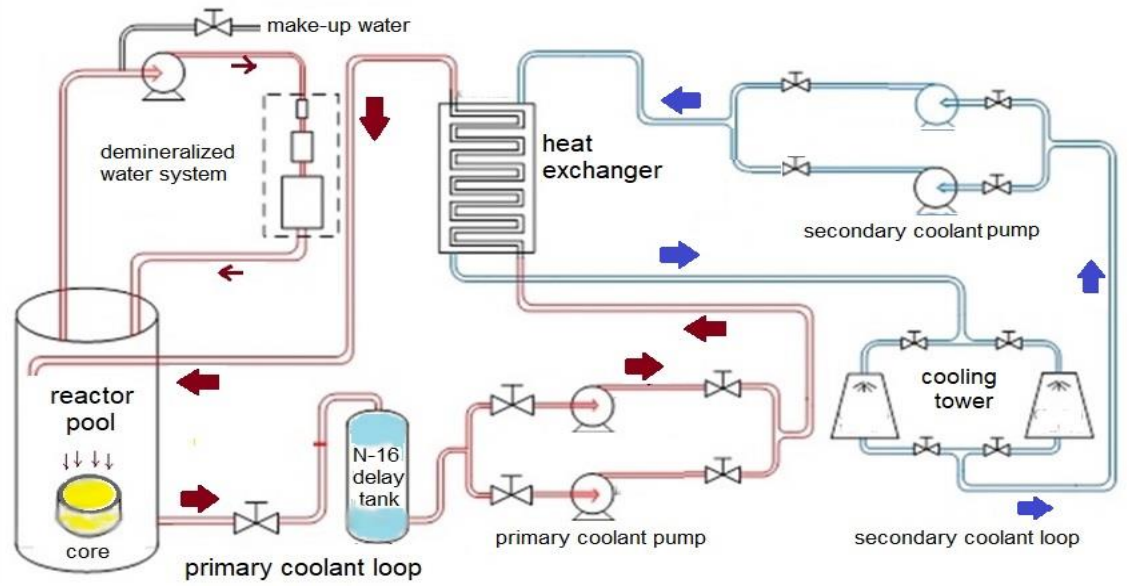

Figure 1. Schematic diagram on modification of the reactor cooling system 


\section{METHOD}

There are several steps in the analysis, namely defining inputs and assumptions. The overall coefficient of heat transfer of the heat exchanger was approximated at $673 \mathrm{~W} / \mathrm{m}^{2}$.K. In which estimated based on the characteristics of the heat exchanger's ability to reduce the primary coolant temperature [18][19]. Furthermore, a model of the reactor coolant diagram is created, the next step is to analyze the primary coolant temperature based on various secondary coolant temperatures from the cooling tower and the reactor power. Table 1 shows the input data used in the analysis.

Table 1. Input data for analysis

\begin{tabular}{clc}
\hline No. & Parameters & Values \\
\hline 1 & $\begin{array}{l}\text { Reactor power, MW } \\
\text { Surface area heat } \\
\text { transfer of heat } \\
\text { exchanger, } \mathrm{m}^{2} \text { [20] }\end{array}$ & 191 \\
3 & $\begin{array}{l}\text { Primary coolant flow- } \\
\text { rate, } \mathrm{kg} / \mathrm{s}\end{array}$ & 50.0 \\
4 & $\begin{array}{l}\text { Secondary coolant flow- } \\
\text { rate, } \mathrm{kg} / \mathrm{s}\end{array}$ & 75.0 \\
& $\begin{array}{l}\text { Coolant temperature } \\
\text { from the cooling tower, } \\
\text { oC }\end{array}$ & 26 to 30 \\
\hline
\end{tabular}

The secondary coolant temperature from the cooling tower depends on the temperature of the environment outside the reactor building during the day, night, and the weather. In this case, a realistic temperature in the range of $26^{\circ} \mathrm{C}$ to $30^{\circ} \mathrm{C}$ is considered. In the next step, steadystate operating data at a power of 0.50 $\mathrm{MW}$ to $1.0 \mathrm{MW}$ is also analyzed.

Meanwhile, some of the assumptions were used like the following conditions;

- the cooling operation is normal/steadystate.

- adiabatic cooling process.

- liquid single-phase coolant flow, no boiling.
- the cooling system and its components refer to the currently installed system specification data.

Running for analysis is carried out using the ChemCad.6.1.4 program as the systematic steps as shown in Figure 2 below;

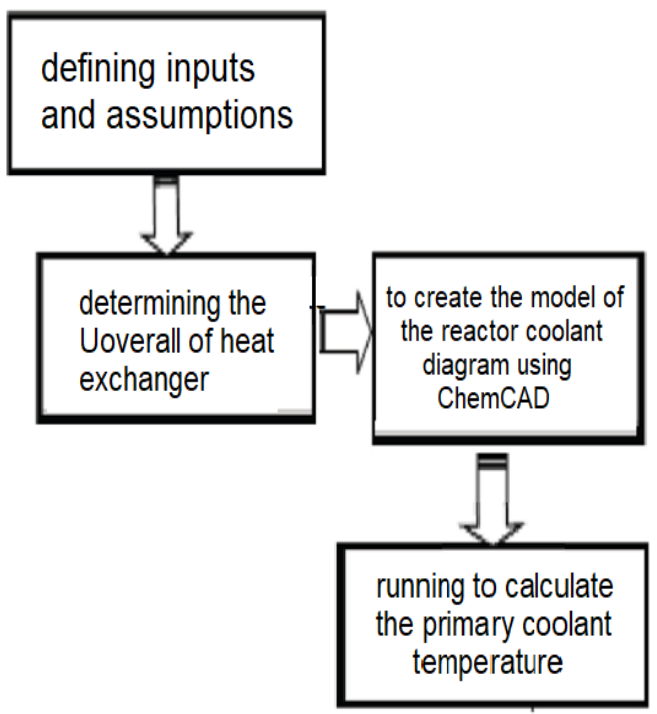

Figure 2. Running steps for analysis

\section{RESULTS AND DISCUSSION}

The analysis results of the reactor cooling system have been carried out for operation at steady-state conditions, namely temperature, pressure, and coolant mass flow rate in both of the primary and secondary cooling systems. The ChemCAD program running has been carried out by setting an appropriate initial input data to achieve convergence of the calculation process.

Figure 3 shows the analysis results for the cooling system operation data using the ChemCAD program in which the input data of coolant temperature from the cooling tower of $28{ }^{\circ} \mathrm{C}$ was determined. In this analysis, the cooling system operates one primary coolant pump with a capacity 
of $50 \mathrm{~kg} / \mathrm{s}$ at the reactor power of $1 \mathrm{MW}$. Flowline diagram no. 4 was simulated with a mass flow rate of $W=0 \mathrm{~kg} / \mathrm{s}$, which means that the pump is not operating. The coolant flow model is adjusted from the split mode (branching). The red line represents the primary cooling loop, and the blue line represents the secondary cooling loop.

The most important parameter data in the operation of the reactor cooling system is the coolant temperature to the reactor core (stream no.1). However, the operating data for all streams in the flow chart of Figure 3 is shown. Then, the important parameters in the flow chart are the operating data of the coolant temperature to the reactor core and the primary coolant pump suction pressure.

As we know, during the operation of the cooling system, degradation of a component will occur that is caused by aging and fouling, especially in the secondary coolant system. In which this coolant system performance can be seen by monitoring the steady-state data directly from the plant.

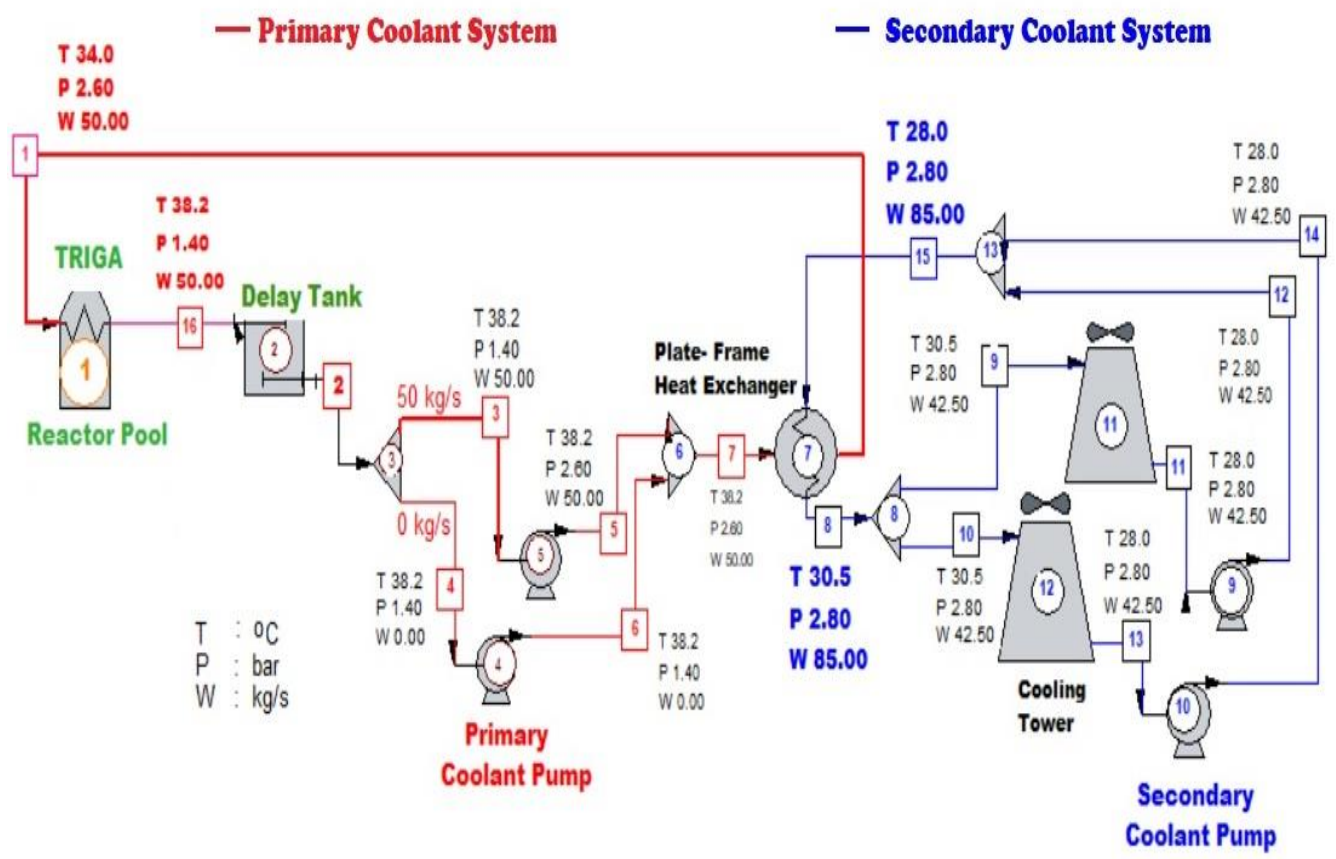

Notes:

The red line: primary cooling system, the blue line: secondary cooling systems

Figure 3. Analysis Results on Steady State Operation Parameters

The data studied included the inlet and outlet temperatures of hot and cold fluids at the heat exchanger (equipment no.7) as well as the cooling tower (equipment no.11 and no.12).
Furthermore, at the time when the operating data shows more than limit values, therefore, periodic maintenance for equipment is considered. 
In the coolant flow that comes out of the reactor core, there is a delay tank $\mathrm{N}-16$ as indicated by component no.2. In this case, the tank delay in this line can cause an increase in the pressure drop of the flow through the pump suction pipe (stream no.2 and no.3) which can cause cavitation [21][22]. The flow pressure drop is caused by friction between fluid and channel wall, bends, changes in shape, and size of the flow cross-section along the pipe ${ }^{[23]}$. Therefore, usually, both the coolant temperatures to the reactor core, and the pump suction pressure indicator are connected to the signal scram to protect the reactor through the RPS (reactor protection system). Then in general, the pressure parameter in the primary and secondary cooling loops is also important, where to avoid the release of radioactive products, the secondary coolant flow pressure must be greater than the primary coolant (pressure indicator stream no.15 and no.7).

Figure 4 shows the analysis results of the primary coolant temperature against coolant temperature from the cooling tower in the range of $26^{\circ} \mathrm{C}$ to 30 ${ }^{\circ} \mathrm{C}$. In the case of coolant temperature from the cooling tower $=30^{\circ} \mathrm{C}$, coolant temperature to the reactor core is achieved of $36{ }^{\circ} \mathrm{C}$ (more than the normal design value of $35^{\circ} \mathrm{C}$ ). Therefore, this value must be considered concerning to the thermal-hydraulic safety aspects of the reactor core although there is still a margin for onset nucleate boiling in the core. Thus, the reactor can be operated safely and reliably.

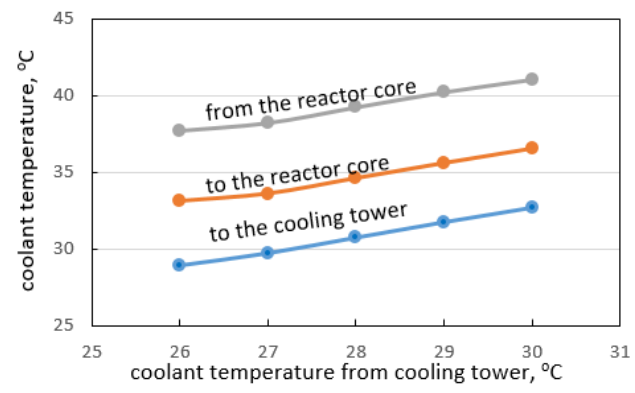

Figure 4. Temperature curve of coolant against coolant from cooling tower

Figure 5 shows the calculation result of coolant temperature when the reactor is operated in a steady-state at a power between $0.5 \mathrm{MW}$ to $1.0 \mathrm{MW}$. In which, the coolant temperature from the cooling tower of $28{ }^{\circ} \mathrm{C}$ was assumed. In general, this data of coolant temperature can be used as an approximate reference in the operation of the reactor cooling system.

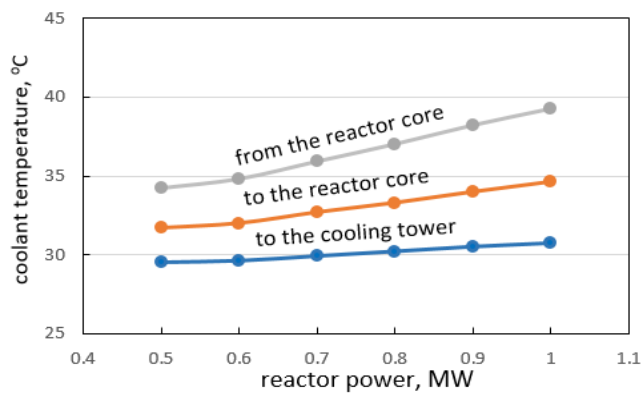

Figure 5 Curve of coolant temperatur against the reactor power

\section{CONCLUSION}

Analysis of the cooling system for a modified TRIGA fuel-plate-type reactor was carried out under steady-state operation using the ChemCAD software. The analysis result shows that the reactor can be operated safely and reliably. However, when coolant temperature to the reactor core is more than the normal design value of $35{ }^{\circ} \mathrm{C}$. It must be 
considered concerning to the thermalhydraulic safety aspects of the reactor core.

\section{ACKNOWLEDGMENT}

The author would like to thank PTKRN Batan and all members of the TRIGA plate conversion team for supporting the research so that this activity can be conducted. The activity is part of the research that was carried out last year using the Insinas program funds for the fiscal year of 2020 .

\section{REFERENCES}

[1] R.H.Oetami, et al., "Radiation Protection Aspect on TRIGA2000 Upgrading Programme“, Indonesian Journal of Nuclear Science and Technology, vol.3, no.2, 2002, pp 119.http://dx.doi.org/10.17146/jstni.20 02. 3.2.2127

[2] H.P. Rahardjo, and V.I.S. Wardani, "The Critical Point of Conversion of Reactor TRIGA 2000 Bandung to Triga Reactor Fuel Plates“, Seminar Nasional Sains dan Teknologi Nuklir 2015, ITB-Bandung, 03/12/2015. http://repo-nkm.batan.go.id/6078/

[3] G.A.Mandala, "Simulasi Modifikasi Reaktor TRIGA2000 Bandung Dengan Bahan Bakar Jenis Pelat", Seminar Nasional VI SDM Teknologi Nuklir Yogyakarta, 18 Nov 2010. https://docplayer.info/30036775-

Simulasi-modifikasi-reaktor-triga2000-bandung-dengan-bahan-bakarjenis-pelat.html

[4] P.Basuki, P.I.Yazid, and Z.Suud, "Neutronic Design Of Plate Type Fuel Conversion For Bandung TRIGA2000 Reactor", Indonesian Journal of Nuclear Science and Technology, vol.15, no.2, pp.69-80, 2014.

http://dx.doi.org/10.17146/istni.2014.15 .2 .1634

[5] S. Dibyo, et al., "Simulation of Modified TRIGA-2000 with Plate Type
Fuel under Lofa Using EUREKA2/RRCode", Atom Indonesia, 44 (1), pp.3136, 2017. https://doi.org/10.17146/ aij.2018.541

[6] S.Widodo, et al.,"Steady-state Thermal-hydraulic Analysis of the TRIGA Plate Core Design by using CoolodN2 and Relap5 codes“, ICoNETS-2019, AIP-Conf.Proc. 2180. doi.org/10.1063/1.5135526

[7] K.A.Sudjatmi, et al.,"Analisis Konveksi Alam Teras Reaktor TRIGA Berbahan Bakar Tipe Pelat Menggunakan CoolodN2", Journal of Nuclear Reactor Technology Tri Dasa Mega, vol. 17 no. 2, pp. 67-78. 2015. http://dx.doi.org/10.17146/tdm.2015.17. 2.2317

[8] E.Umar, K.Kamajaya, and A.I.Ramadhan, "Evaluation of the Pump Capability of the Primary Cooling of TRIGA2000 Research Reactor", IOP Publishing Ltd. ICANSE 2018, Journal of Physics: Conf.Series1493, 2020, 012018. doi:10.1088/1742-6596/1493/1/012018

[9] A. Jami, and H.L. Nuri, "Line Sizing Jalur Pipa Sistem Pendingin Primer Reaktor TRIGA Plat", PRIMA, vol.15, no.2, 2018.

http://jurnal.batan.go.id/index.php/pri ma/article/view/5158/4474

[10] V.I.S.Wardhani, H.P. Rahardjo, and R. Tursinah, "Routing Design on The Primary Cooling Piping System in Plate Type Converted TRIGA 2000 Reactor Bandung“, Journal of Nuclear Reactor Technology Tri Dasa Mega, vol. 21 no. 3, pp.107-112. 2019. http://dx.doi.org/10.17146/tdm.2019.21. 3.5603

[11] K.Solanki, and N.Patel,"Process Optimization Using ChemCAD“. Int. J. Futur. Trends Eng.Tech.1(2), pp.4751, 2014. https://ijftet.wixsite.com/ research/special-issue-azeotrope14

[12] S.Dibyo, I.D.Irianto, and S.Pujiarta, "Evaluation of Operating performance 
of the Reactor Coolant System of RSG-GAS Using ChemCAD.6.1.4“, ICONETS Proceedings International Conference on Nuclear Energy Technologies and Sciences (2015), Vol.2016. doi:10.18502/ken.v1i1.460

[13] V.I.S.Wardhani, "Influence of the Adding Bottom-up Flow Rate to the Characterictic of the Cooling System on TRIGA 2000 Reactor Core“, Jurnal Iptek Nuklir Ganendra, vol.13 no.2, pp 56-63, 2010.

http://jurnal.batan.go.id/index.php/ga nendra/article/view/47

[14] S.Dibyo, S.Pinem, and V.I.S.Wardhani, "Conceptual Design on N16 Decay Chamber for Modified TRIGA-2000 with Plate-Type Fuel“, Jurnal Pengembangan Energi Nuklir, vol. 20, no.1, pp. 25-30, 2018.

http://dx.doi.org/10.17146/jpen.2018.20 .1 .4278

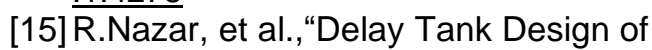
bandung TRIGA Plate Reactor", Indonesian Journal of Nuclear Science and Technology, vol.19, no.2, pp. 91-108, 2018. https://doi. org/10.17146/jstni.2018.19.2.4140

[16] M.A. Hoq, et al., "Assessment of N-16 Activity Concentration In Bangladesh Atomic Energy Commission TRIGA Research Reactor", Nuclear Engineering and Technology, 2017doi.org/10.1016/j.net.2017.11.006

[17] V.I.S.Wardhani, J.S.Pane, and S.Dibyo, "Analysis of Coolant Flow Distribution to the Reactor Core of Modified TRIGA Bandung with PlateType Fuel", IOP Conf. Series: Journal of Physics: Conf.Series1436, 2020. 012098, IOP Publishing. doi:10.1088/1742-6596/1436/1/012098
[18]P.R.Henky and V.I.S.Wardhani, "The Characteristic and heat exchanger effectivity Reactor TRIGA-2000 Bandung after cleaned“, Indonesian Journal of Nuclear Science and Technology, vol.8, no.1, pp.43-64, 2007.http://dx.doi.org/10.17146/jstni.20 07.8 .1 .2150

[19] P.R.Henky, et al., "Fouling Deposit Prediction of Plate Type Heat Exchanger", Indonesian Journal of Nuclear Science and Technology, vol.IV, no.1, pp 43-64, 2003.

https://media.neliti.com/media/publicati ons/

[20] A.Jami and H.L.Nuri, "A Plate Heat Exchanger Design for Plate Triga Reactor by ChemCAD Application Software“, PRIMA, vol.14, no.1, 2017. http://jurnal.batan.go.id/index.php prima/article/view/3869

[21] Safrul and S.Dibyo,"Analisis Tekanan Aliran Pada Sisi Hisap Pompa Primer RSG-GAS“, jurnal forum nuklir, vol.7, no.1, 2013. https://doi.org/10.17146/ jfn.2013.7.1.3461

[22] V.Cucit, et al., "A Control System For Preventing Cavitation of Centrifugal Pumps“, 3rd Conference of the Italian Thermal Machines Engineering Association ATI 2018, Pisa, Italy, ScienceDirect Energy Procedia 148, pp. 242-249, 2018. doi:10.1016/i.egypro.2018.08. 074

[23] S.Dibyo,"Kajian Dalam Penentuan Faktor Friksi Aliran Pendingin", Prosiding Seminar Hasil Penelilian P2TRR 2002: p.203.

https://inis.iaea.org/collection/NCLCol lectionStore/ Public/38/115/3811535 3.p 